\title{
Analisis Elemen Al-Hajah Dalam Pembiayaan Peribadi (Analysis of Element Al-Hajah In Personal Financing)
}

\author{
Muhammad Ikhlas Rosele ${ }^{\mathrm{a}, *}$ \\ Jabatan fiqh dan Usul, Akademi Pengajian Islam, Universiti Malaya. \\ a,* Corresponding author: ikhlas@um.edu.my
}

\author{
Article history \\ Received: 2016-12-01 \\ Received in revised form: 2017-05-24 \\ Accepted: 2017-07-04
}

\begin{abstract}
Abstrak
Pembiayaan peribadi merupakan keperluan masyarakat pada hari ini. Namun, dalam konteks perbankan Islam, kontrak pembiayaan peribadi (bay' al-'inah dan al-tawarruq) telah menimbulkan polemik dan isu. Hal ini lanjutan perselisihan ulama terhadap hukum kontrak tersebut, bahkan majority ulama tidak mengharuskannya. Oleh itu, dengan menggunakan pendekatan kualitatif dan berasaskan data-data kepustakaan, artikel ini akan menjelaskan dukungan hujah untuk menerima atau mengharuskan kontrak pembiayaan peribadi tersebut. Hasil kajian mendapati bahawa pembiayaan peribadi merupakan satu keperluan di tahap al-hajah dan ia juga boleh mengambil kedudukan al-darurah dalam keadaan tertentu. Oleh itu, adalah wajar elemen al-hajah dipertimbangkan dalam menentukan status hukum kontrak pembiayaan peribadi yang diamalkan dalam perbankan Islam di Malaysia.
\end{abstract}

Kata kunci: pembiayaan peribadi, bay' al- 'inah, al-tawarruq, perbankan Islam, al-hajah

\begin{abstract}
Personal financing is a one of the society's needs nowadays. However, in Islamic banking context, underlying contract of personal financing namely bay' al-'nah and al-tawarruq has raised issues and polemic. The main cause of this polemic is due to the differences in juridical opinions from ulama' on these contracts, which in fact, the majority of them has prohibited bay' al-'inah and al-tawarruq al-munazzam contract. Thus, this study employed qualitative approach and library sources to explain the alternative argument in accepting and allowing these contracts to be use in personal financing instrument. The result of this study shows that personal financing has become a necessity (al-hajah) and also able to take place up to al-darurah (compulsion) level in certain condition. Therefore, it is sensible to take the element of al-hajah as a consideration in determining the juridical opinion on personal financing contract in Malaysia.
\end{abstract}

Keywords: Personal financing, bay' al- 'inah, al-tawarruq, Islamic banking, al-hajah 


\subsection{PENDAHULUAN}

Antara produk perbankan yang mendapat sambutan pelanggan adalah pembiayaan peribadi secara Islam. Di Malaysia pembiayaan peribadi Islam ditawarkan lazimnya oleh bank seperti Maybank Islamic, Bank Islam Malaysia Berhad, RHB Islamic, Bank Muamalat dan sebagainya (Nor Fadilah \& Nuzul Akhtar, 2014). Denga adanya penawaran produk ini, masyarakat boleh mendapat tunai untuk dibelanjakan kepada apa jua bentuk barangan dan keperluan mereka. Berbeza dengan produk pembiayaan kenderaan dan perumahan di mana pelanggan tidak bebas untuk menggunakan pembiayaan tersebut untuk tujuan yang lain. Namun, dalam konteks perbankan Islam, tidak wujud kontrak pembiayaan peribadi yang diharuskan dan diterima oleh sebilangan besar fuqaha. Oleh kerana itu, isu kontrak dalam pembiayaan peribadi sentiasa menjadi polemik.

Artikel ini ditulis untuk melihat wujudnya ruang yang boleh menjadi hujah dukungan dalam mengaplikasikan kontrak yang dianggap kontrovesi di Malaysia iaitu bay' al- 'inah dan al-tawarruq. Ruang yang dimaksudkan adalah untuk menyokong pengharusan kontrak pembiayaan peribadi berasaskan hujah al-hajah. Justeru artikel ini akan membahaskan dan menjelaskan mengenai isu kontrak dalam pembiayaan peribadi dan keperluannya pada hari ini serta konsep al-hajah dan kaitannya dengan pembiayaan peribadi.

\subsection{ISU KONTRAK DALAM PEMBIAYAAN PERIBADI}

Pembiayaan peribadi merupakan satu kemudahan kewangan yang ditawarkan lazimnya oleh bank. Produk ini ditawarkan bertujuan memberi kemudahan tunai kepada pelanggan serta memudahkan mereka mendapatkan sesuatu barang atau perkhidmatan kegunaan peribadi secara bayaran mudah (Mohd Daud Bakar, 2011). Terdapat tiga ciri yang utama dalam pembiayaan peribadi iaitu (Mohd Farhan \& Mohd Adib, 2011):

1. Urusan dan prosedur mendapatkan pembiayaan peribadi adalah lebih mudah daripada memohon pembiayaan lain seperti pembiayaan rumah dan sebagainya.

2. Tempoh bayaran semula adalah pendek kerana pembiayaan ini menawarkan jumlah pembiayaan lebih kecil daripada pembiayaan yang lain.

3. Barang dan perkhidmatan yang dibiayai adalah lazimnya barang untuk keperluan kepenggunaan.

Pembiayaan peribadi dalam sistem perbankan Islam kini lazimnya berasaskan kepada salah satu daripada tiga jenis kontrak iaitu; kontrak bay' al- 'inah, kontrak tawarruq dan al-rahnu. Walaupun begitu, ketiga-tiga kontrak tersebut mempunyai isu hukum yang menjadi perbahasan dalam kalangan intelektual Islam. Justeru, artikel ini akan menjelaskan konsep kontrak bay' al- 'inah dan kontrak tawarruq serta isu hukum yang timbul padanya. Kontrak alrahnu tidak difokuskan secara langsung dalam artikel ini kerana konsep perlaksanaannya berbeza dengan bay' al'inah dan al-tawarruq.

\section{Kontrak Bay’al-'Inah}

Kontrak bay' al-'inah adalah antara kontrak pembiayaan untuk mendapatkan tunai yang diamalkan di Malaysia. Bay' al- 'inah bermaksud satu urusniaga apabila seseorang menjual barangan secara tangguh, kemudian membelinya semula secara tunai dengan harga yang lebih rendah (Wizarah al-Awqaf, 1983). Al-Mawsu;ah alFiqhiyyah menjelaskan maksud bay' al-'inah adalah sebagai kontrak hutang dalam bentuk jual beli untuk memperolehi lebihan (untung) (Wizarah al-Awqaf, 1983).

Contoh mudah gambaran transaksi bay' al- 'inah adalah seperti berikut; Yusuf memerlukan wang tunai untuk kegunaanya lalu dia pergi kepada Amir yang melakukan aktiviti bay' al- 'inah. Kemudian, Amir menjual satu komoditi dengan nilai RM 12,000 kepada Yusuf secara tangguh (yang perlu dilunaskan Yusuf secara ansuran) dan komoditi tersebut dibeli semula secara tunai oleh Amir dengan nilai RM 10,000. Kesan daripada aktiviti itu, Yusuf memperolehi tunai sebanyak RM 10,000 manakala Amir mendapat keuntungan sebanyak RM 2,000 daripada aktiviti tersebut. 
Jumhur Fuqaha' yang terdiri dari golongan Hanafiyyah, sebahagian Malikiyyah dan Hanabilah berpendapat bahawa bay' al- 'inah adalah kontrak yang rosak (fasid) ataupun terbatal. Mereka berhujah dengan larangan keras yang terdapat di dalam sebuah hadis Nabi s.a.w mengenai larangan jual beli secara al-inah (al-Maqdisi, 1997; Azizi, 2009). Pengharamannya juga adalah berasaskan sad al-zara' $i$ ', iaitu menutup jalan untuk sebarang kerosakan (al-Zuhayli, 1985). Selain itu, pengharaman ini selaras dengan satu kaedah iaitu al-wasail al-haram haram (wasilah kepada yang haram adalah haram) (al-Maqdisi, 1997). Al-Syatibi (1997) menyatakan bahawa sad al-zarai' dalam transaksi bay' al-'inah adalah kerana; pertama, bay' al-i'nah kebiasaannya bertujuan menghalalkan riba. Kedua, pada hakikatnya ia boleh mendatangkan mudarat kepada manusia walaupun kontrak jual beli pada asasnya diharuskan. Jika wujud pertentangan antara kedua perkara tersebut, maka kaedah daf' al-mudarrat muqaddam min jalb al-manafi' adalah terpakai. Ketiga; sesuatu yang asalnya diizinkan boleh menjadi perkara yang dilarang sekiranya mendatangkan keburukan.

Manakala golongan Syafi'iyyah dan Zahiriyyah menganggap bahawa kontrak bay' al-'inah adalah sah (alZuhayli, 1985; al-Nawawi, 2003). Hal ini berikutan sesuatu kontrak dilihat pada zahirnya, jika ia mencukupi syarat jual beli maka transaksi tersebut adalah sah. Golongan ini berhujah dengan keumuman nas al-Quran (2: 275). Selain itu ia boleh diqiyaskan dengan jual beli senjata kepada pemberontak dan jual beli anggur pada pembuat arak di mana kontrak tersebut adalah sah walaupun makruh (al-Syarbini, 1997).

Di Malaysia pengamalan bay' al- 'inah adalah bersandarkan kepada pendapat dalam Mazhab Syafi'i dan Zahiri kerana menurut mereka akad hanya dilihat dari sudut zahir sahaja manakala hadis-hadis larangan bay' al- 'inah yang dijadikan hujah oleh golongan yang menolak kontrak tersebut adalah lemah dan tidak boleh dijadikan hujah (Shamsiah \& Ameer Azeezy, 2007). Walaupun begitu, pelanggan telah mula mempersoalkan kehalalan produk yang ditawarkan berasaskan kontrak bay' al- 'inah yang ditawarkan oleh Institusi Kewangan Islam dan penolakan terhadap praktik kontrak tersebut telah meningkat (Amir, 2013).

\section{Kontrak Tawarruq}

Lanjutan daripada isu yang timbul dalam kontrak bay' al-'inah telah menyebabkan kebanyakan institusi perbankan Islam mula berpindah kepada kontrak alternatif iaitu kontrak al-tawarruq (Wan Jemizan, 2010; Mahmud, 2012). Kontrak al-tawarruq (dalam pentakrifan klasik) suatu transaksi yang dilakukan dengan membeli suatu komoditi dengan harga yang tinggi, sama atau murah secara tangguh untuk dijual semula kepada orang lain sebagai pihak ketiga (bukan kepada penjual asal komoditi tersebut) untuk mendapatkan tunai (al-Bahuti, 2000).

Namun alternatif tawarruq yang diperkenalkan ini (dalam sistem perbankan Islam) dikatakan masih tidak bertepatan dengan konsep tawarruq yang sebenar, ini kerana ia tidak selaras dengan kontrak tawarruq sebagaimana yang terdapat di dalam perbahasan fiqh. Dalam amalan perbankan Islam pada hari ini prinsip kontrak al-tawarruq yang sebenar sukar untuk dilaksanakan, bahkan secara tidak langsung ia berpindah kepada kontrak al-tawarruq almunazzam (al-Khathlan, 2012) ataupun muhallil al-riba'. Namun begitu, hukum al-tawarruq al-munazzam diperselisihkan oleh ulama kontemporari, kebanyakan mereka mengharamkannya kerana wujud unsur hilah ribawi dan serupa dengan kontrak bay' al- 'inah, manakala sebahagian mereka pula membenarkannya kerana asasnya transaksi yang dilakukan adalah sah (Nasrun \& Asmak, 2014).

Terdapat beberapa fatwa yang telah memutuskan bahawa kontrak al-tawarruq al-munazzam adalah haram seperti Fatwa Lajnah al-Da'imah, al-Ri'asah al-'Amah li al-Buhuth al-'Ilmiyah wa al-Ifta' kerajaan Arab Saudi (t.t.) dan Majlis al-Ifta' kerajaan Jordan (t.t.). Walaupun begitu, isu al-tawarruq al-munazzam ini telah mendapat perhatian dan dipertimbangan di Malaysia, bahkan telah wujud alternatif atau garis panduan dalam amalan perbankan Islam untuk mengelakkan terjadinya isu tersebut.

Pada dasarnya komoditi (barang) yang dibeli oleh pelanggan daripada pihak bank dapat dijual kepada pihak ketiga atas bantuan bank. Pihak ketiga yang dimaksudkan adalah yang tidak mempunyai kaitan (persepakatan) dengan bank sebagai penjual asal komoditi tersebut. Hal ini, boleh dilihat dalam amalan Bank Islam Malaysia Berhad dan RHB Islamic Bank (Siti Aishah \& Kamaruzaman, 2014). Namun, dalam amalan tersebut tetap melibatkan isu-isu syariah yang lain seperti elemen gharar (ketidak pastian) (Hussein Azeemi, Muhamad Firdaus \& Azman, 2014), bay' al-ma'dum (kerana pembelian dilakukan secara konstruktif), isu pertindihan akad pada satu komoditi dan isu pra-aturan (tawatu') (Mohd Izuwan, 2015).

Ibn al-Qayyim telah menjelaskan hubungan al-tawarruq dengan bai' al- 'inah ataupun muhallil al-riba, iaitu; Sekiranya dia membelinya untuk dijualkan kepada orang lain (bukan penjual asal) maka ia adalah al-tawarruq. Sekiranya ia kembali kepada orang ketiga yang ada kaitan dengan mereka berdua (yang dirancang) maka ia adalah muhallil al-riba (Ibn al-Qayyim, 2004). 
Oleh kerana itu, dalam realiti di Malaysia khususnya, isu ini masih perlu diperbincangkan untuk mencari penyelesaian adakah bay' al- 'inah masih wajar diaplikasikan ataupun menukarkannya kepada kontrak al-tawarruq sepenuhnya. Begitu juga, kajian atau perbahasan mengenai alternatif lain yang boleh digunakan untuk memenuhi keperluan pembiayaan peribadi di Malaysia selain aplikasi bay' al-'inah dan al-tawarruq. Ataupun adakah wujud keringanan syarak yang boleh diambilkira untuk mengharuskan kontrak pembiayaan peribadi yang terdapat sekarang.

\subsection{KEPERLUAN TERHADAP PEMBIAYAAN PERIBADI}

Di Malaysia khususnya, kehidupan masyarakat berkembang dan semakin maju sehingga mewujudkan banyak persaingan. Persaingan dan usaha untuk meneruskan kehidupan adalah sesuatu yang tidak dapat dielakkan demi memperolehi keadilan sosial dan kestabilan ekonomi individu, keluarga mahupun masyarakat. Rentetan itu, masyarakat memerlukan sokongan ekonomi atau kewangan sama ada berbentuk tunai mahupun material. Antara pihak yang dapat memenuhi kehendak masyarakat ini antaranya adalah bank, koperasi dan badan-badan kewangan lain melalui produk pembiayaan peribadi (Asmak, Shamsiah \& Iman, 2010).

Realiti tersebut telah menjelaskan secara umum keperluan kepada pembiayaan peribadi dalam kalangan masyarakat demi mencapat matlamat asas kehidupan (Ab. Rahim, 2015). Selain itu, keperluan kepada pembiayaan peribadi berteraskan Islam sangat dititikberatkan untuk mengelakkan umat Islam secara jelas dan nyata terlibat dalam urusniaga berteraskan riba (Azizi, 2009). Namun persoalannya sejauh manakah keperluan terhadap pembiayaan peribadi dalam kalangan masyarakat. Adakah ia berada di peringkat keperluan mendesak (daruriyyah), ataupun pada peringkat keperluan sederhana (hajiyyat) atau sekadar memperolehi keselesaan (tahsiniyyat).

Namun jika diamati konsep al-darurah atau al-daruriyah adalah merujuk kepada satu keperluan yang sangat mendesak. Ia boleh diertikan sebagai satu bentuk maslahah yang berkait dengan kehidupan atau nyawa manusia, di mana sekiranya maslahah tersebut tiada maka kehidupan manusia akan binasa (al-Zuhayli, 2010). Ataupun dalam erti kata lain, ia merupakan kepentingan yang sangat diperlukan bagi mencapai kemaslahatan hidup sama ada pada aspek keagamaan ataupun keduniaan. Tanpanya akan menyebabkan kemaslahatan hidup tidak berterusan bahkan mengalami kerosakan (al-Syatibi, 1997).

Sebagai contoh, seseorang yang tiada makanan yang halal untuk dimakan (kerana sesat) kecuali bangkai, sekiranya dia tidak memakan bangkai tersebut nyawanya akan hilang, maka diharuskan untuk dia memakan bangkai ketika itu kerana al-darurah (al-Jassas, 1993; al-Jawzi, 1987). Demikian juga penggunaan ubat atau vaksin dari bahan yang haram, adalah diharuskan apabila tiada pilihan dari ubat-ubat yang halal sekiranya wujud keperluan yang bersifat al-darurah dan al-hajah (Rohani, 2012).

Al-Tahsiniyyat pula adalah peringkat terendah keperluan manusia, ia adalah satu bentuk pelengkap atau yang memenuhi keperluan yang lain. Contohnya, rumah adalah satu keperluan yang bersifat daruriyah, bekalan elektrik adalah hajiyyat dan peralatan elektik lain seperti television atau pemanas air adalah satu keperluan yang bersifat tahsiniyyat.

Oleh itu, pada asasnya dapat difahami bahawa pembiayaan peribadi tidak boleh ditempatkan pada kedua-dua peringkat keperluan iaitu peringkat al-daruriyyah dan al-tahsiniyyat. Keperluan pembiayaan peribadi yang ditawarkan oleh institusi kewangan Islam tidak boleh dikategorikan pada peringkat al-daruriyyah kerana ia tidak melibatkan soal nyawa mahupun hidup manusia. Namun, pembiayaan peribadi masih suatu keperluan untuk menstabilkan kehidupan dan menampung urusan kehidupan seperti untuk digunakan sebagai pembiayaan persekolahan anak, membeli barang keperluan untuk tujuan pekerjaan dan seumpamanya, dengan kata lain ia tidak boleh dikategorikan dalam peringkat al-tahsiniyyat. Atas alasan tersebut, dapat disimpulkan bahawa pembiayaan peribadi berada pada kedudukan al-hajiyyat.

\subsection{KONSEP $A L-H A J A H$}

Perbahasan al-hajah sangat penting bagi kajian ini. Hal ini kerana ia menjadi kayu ukur untuk melihat kedudukan dan sejauh mana pembiayaan peribadi (berasaskan kontrak bay' al-'inah dan al-tawarruq) boleh diaplikasikan di Malaysia. Sub-topik ini akan membincangkan mengenai definisi al-hajah, ruang lingkupnya dan beberapa panduan yang berkait dengannya, 
Ulama' Islam telah memberi takrifan terhadap al-hajah. Menurut 'Izz al-Din 'Abdul Salam (2000) definisi alhajah adalah:

“Apa yang berada di antara darurah (keperluan) dan takmilah (pelengkap)”

Menurut Imam al-Syatibi (1997) pula al-hajah adalah:

"Keperluan kepadanya kerana melapangkan atau menyenangkan yang mana menghilangkan kesempitan yang biasanya membawa kepada kesusahan dan kesulitan yang berkaitan dengan hilangnya perkara yang dituntut, sekiranya (perkara hajiyyat) itu tidak diraikan para mukallaf itu akan terjerumus kedalam kesusahan dan kesulitan, tetapi ianya tidaklah sampai ketahap mendatangkan kerosakan dalam kemaslahatan umum”

Antara ulama semasa yang memberi makna al-hajah adalah Yusuf al-Qaradawi. Menurut al-Qaradawi (1996) al-hajah membawa maksud:

"Apa yang manusia mungkin boleh hidup tanpanya tetapi disertai kesukaran dan kesempitan".

Penjelasan yang dikemukakan oleh al-Syatibi lebih panjang dan ia telah menjelaskan ruang lingkup al-hajah. Oleh itu, dapat disimpulkan bahawa tanpa sesuatu yang bersifat al-hajah tidak mendatangkan kerosakan dan menjejaskan kemaslahatan umum. Namun, tanpanya boleh menyebabkan seorang mukallaf tersebut menjadi sempit dan susah. Meraikan al-hajah pada asasnya bertepatan dengan prinsip syariat Islam yang bertujuan untuk mengelakkan kepayahan dan kesusahan bagi penganutnya. Firman Allah s.w.t;

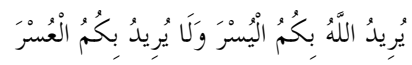

Yang bermaksud; Allah menghendaki bagi kamu kesenangan dan tidak menghendaki bagi kamu kepayahan. (Surah al-Baqarah, 2: 185)

Sebelum memberi kesimpulan terhadap kedudukan pembiayaan peribadi sebagai al-hajah, adalah wajar untuk dijelaskan bahawa terdapat keadaan al-hajah boleh mengambil kedudukan al-darurah. Hal ini juga memungkinkan bahawa walaupun pembiayaan peribadi yang mulanya bersifat al-hajah boleh mengambil tempat al-darurah. Kenyataan ini adalah berasaskan kaedah fiqh yang menyebut (Ibn Nujaym, 2005);

$$
\text { الحاجة تنزل منزلة الضرورة }
$$

\section{Al-Hajah boleh menggantikan tempat al-darurah}

Namun, terdapat perbahasan mengenai adakah hanya al-hajah yang bersifat umum boleh menggantikan aldarurah yang khusus sahaja. Ulama' terdahulu antaranya ada menyatakan bahawa al-hajah yang umum hanya boleh menggantikan al-darurah yang khusus sahaja, seperti yang dinyatakan oleh imam al-Haramayn; "al-hajah al- 'amma tunazzal manzilah al-darurah al-khassah fi haq ahad al-asykhas” ('Abdul Malik, 1399H).

Namun ulama terkemudian telah mengemukakan suatu kaedah yang lebih membuka ruang, dimana al-hajah bukan sahaja hanya menggantikan al-darurah yang khusus bahkan al-darurah yang umum, iaitu "al-hajah tunazzal manzilat al-darurah 'ammah kanat am khassah" (al-Sayuti, 1997).

Kelonggaran syara' (al-tashilat al-syar'iyah) yang menjadi jalan pengecualian kerana meraikan maslahah dan kepentingan manusia tidak semestinya dalam bentuk al-darurah yang berat. Bahkan sekiranya al-hajah segolongan manusia ataupun masyarakat juga merupakan kelongaran yang mendapat pengecualian hukum (al-Hariri, 1998). Oleh kerana itu, beberapa akad muamalah diharuskan berasaskan kaedah ini seperti; al-ijarah, , bay' al-salam, bay' al-istishna', al-ji'alah dan al-hiwalah (al-Burnu, 2003). Bahkan jika diamati, al-hajah lebih perlu diraikan kerana ia melibatkan keperluan manusia yang lebih konsisten sedangkan keperluan yang bersifat al-darurah adalah berwaktu (al-Zarqa, 2001). Hal ini juga menghasilkan satu hukum yang bersifat konsisten dan sentiasa meraikan kemaslahatan umat Islam.

Al-Hajah terbahagi kepada dua iaitu hajah umum dan hajah khusus. Al-Hajah yang khusus perlu mencukupi beberapa syarat barulah ianya boleh diambilkira dalam penentuan hukum atau mengantikan al-darurah. Sekiranya dikaitkan dengan pembiayaan peribadi ianya merupakan al-hajah yang umum, bukannya al-hajah yang khusus. Ini 
adalah kerana, walaupun pada dasarnya ia diperlukan oleh individu atau sekumpulan orang namun ia mempunyai tujuan yang umum dan demi menjaga kemaslahatan umat manusia. Ia adalah untuk menjamin masyarakat daripada kesempitan dan kesusahan dalam mengurus kehidupan lebih-lebih lagi dalam suasana ekonomi yang tidak stabil.

Pengambilkiraan al-hajah dalam sesuatu keadaan perlu mempunyai garis panduan tertentu. Hal ini untuk mengelakkan sebarang unsur penyalahtafsiran dan penggunaanya secara tidak berdisplin. Garis panduan atau syarat untuk menetapkan al-hajah adalah perlu terutamanya dalam keadaan ia mengambil tempat al-darurah. Berikut adalah syarat-syarat untuk menentukan al-hajah (al-Zair \& Hamzah, 2010);

1. Hendaklah mempunyai asas yang dii'tibar mengikut syara' dan hampir menyamainya dan kaedahkaedah yang bertepatan dengan prinsip-prinsip dan objektif syara'. Contoh keadilan, mahukan anak dan lain-lain.

2. Hendaklah berlakunya al-hajah itu secara yakin ataupun $d z a n$

3. Hendaklah al-hajah itu sesuatu yang tidak dapat diganti

Dalam konteks pembiayaan peribadi ia adalah suatu keperluan yang berlaku secara yakin. Hal ini jelas dengan penawaran dan sambutan terhadap produk pembiayaan peribadi yang ditawarkan oleh institusi kewangan Islam. Selain itu, dalam aspek pembiayaan peribadi, tiada kontrak yang dapat mengambil tempat bay' al- 'inah dan altawarruq sehingga memenuhi ciri-ciri memberi keuntungan pada pihak bank di samping memberi kemudahan tunai kepada orang yang memerlukan. Mungkin wujud tanggapan bahawa prinsip al-rahnu boleh menggantikannya, namun apabila diteliti kontrak al-rahnu dianggap tidak mesra pelanggan. Hal ini kerana, pelanggan perlu memiliki aset yang bernilai untuk mendapatkan tunai (Amir Fazlim \& Muhammad Shahir Ridzuan, sedangkan orang yang memerlukan pembiayaan peribadi lazimnya tidak memilik aset tersebut. Manakala prinsip menghilangkan kesempitan dalam pengamalan pembiayaan peribadi adalah salah satu dari prinsip-prinsip syarak (Zaydan, 2009).

Al-Mumini (2004) pula telah melakukan garis panduan atau syarat al-hajah dengan lebih terperinci. Beliau telah membahagikan syarta al-hajah kepada syarat-syarat umum dan syarat-syarat khusus. Syarat-syarta tersebut adalah sebagaimana berikut;

Syarat-syarat umum:

1. Tidak boleh menggunakan pertimbangan al-hajah dalam lapangan prinsip-prinsip akidah dan kaedahkaedah syariat.

2. Tidak menggunakan pertimbangan al-hajah dalam perkara yang bercanggahan dengan objektif syari'ah

3. Tidak mengutamakan pertimbangan al-hajah untuk membandingi pertimbangan al-darurah

4. Al-Hajah tersebut tidak bercanggah dengan nas syara'

5. Al-Hajah tersebut tidak bercanggah dengan ijma' yang qat' $\mathrm{i}$

Syarat-syarat khusus:

1. Hendaklah al-hajah itu berlaku

2. Hendaklah terhad pengunaannya sekadar melepaskan al-hajah tersebut

3. Hendaklah al-hajah tersebut al-hajah yang muta'ain (tidak ada gantinya)

4. Wujudnya kesempitan dan kesukaran sekiranya tidak melaksanakan perkara al-hajah tersebut

Seperti mana yang telah dijelaskan bahawa kontrak bay' al-'inah atau al-tawarruq yang menjadi kontrak pendasar kepada pembiyaan peribadi secara kasarnya tidak bercanggah dengan objektif syarak, nas yang sarih dan ijmak. Oleh kerana itu, ia diterima oleh golongan syafi'iyyah. Bahkan ia dapat mengelakkan manusia dari kesempitan dalam realiti hidup hari ini. 


\subsection{ELEMEN AL-HAJAH DALAM PEMBIAYAAN PERIBADI}

Sebagaimana yang telah dijelaskan sebelum ini, pembiayaan peribadi dalam realiti hari ini mengambil posisi alhajah. Ia diperlukan masyarakat untuk mengelakkan daripada kesulitan dan kesempitan. Namun, produk pembiayaan peribadi yang ditawarkan oleh institusi kewangan Islam di Malaysia iaitu bay' al-'inah dan al-tawarruq didapati mempunyai isu-isu hukum. Ia dibahaskan dan menjadi topic penting dalam kalangan intelektual Islam di Malaysia. Oleh itu, setelah menjelaskan kedudukan al-hajah dalam hukum Islam serta kedudukan pembiayaan peribadi yang memenuhi prinsip al-hajah, kajian menyimpulkan bahawa hukum pembiayaan peribadi berasaskan kontrak tersebut boleh diharuskan atas beberapa alasan, iaitu;

Pertama, pembiayaan peribadi adalah satu keperluan yang bersifat al-hajah. Ia dapat mengelakkan umat Islam daripada kesulitan dan kesempitan hidup. Oleh kerana itu, kontrak pembiayaan peribadi yang ditawarkan oleh institusi kewangan Islam boleh diharuskan.

Kedua, hukum bay' al- 'inah adalah diperselisihkan oleh ulama'. Golongan Syafi'iyyah mengharuskannya dan menyatakan kontrak yang termetrai dalam amalan bay' al-'inah adalah sah. Walaupun hujah dan alasan yang dikemukakan mendapat pertikaian oleh intelektual lain, ia boleh didokong dengan hujah al-maslahah. Hal ini kerana, tanpa aplikasi kontrak tersebut, urusan hidup umat Islam menjadi terhad dan sempit, sedangkan prinsip utama syariat Islam adalah mengangkat kesukaran dan member keringanan. Al-Maslahah yang dimaksudkan di sini adalah mengambil kira pertimbangan al-hajah dalam urusan kehidupan khususnya dalam isu pembiayaan peribadi. Kemaslahatan ini boleh menjadi alasan untuk mentarjihkan pandangan golongan Syafi'iyyah.

Ketiga, setakat ini tidak ada alternatif lain yang boleh mengambil tempat kontrak bay' al- 'inah dan tawarruq atau lebih tepat lagi tawarruq munazzam dalam pembiayaan peribadi. Kontrak al-qard tidak dapat dilaksanakan oleh kerana perubahan zaman yang menyaksikan keruntuhan akhlak dan kepercayaan masyarakat. Ia menyebabkan ketidakyakinan pulangan semula pinjaman yang telah ditawarkan dan ia mendatangkan kerugian kepada pemberi pinjam. Manakala al-rahnu bukanlah alternatif yang sesuai untuk menyelesaikan keperluan umat Islam. Ini kerana, tidak semua masyarakat mempunyai kekayaan berbentuk aset untuk dicairkan. Bahkan kebanyakan masyarakat tidak mempunyai aset tersebut sehingga membuat hidup mereka menjadi sempit dan sulit. Oleh itu, keperluan terhadap kontrak pembiayaan peribadi adalah sesuatu yang jelas, nyata (yakin dan berlaku) dan tidak mempunyai alternatif lain menggantikannya, dalam erti kata lain ia telah memenuhi syarat al-hajah.

\subsection{KESIMPULAN}

Bersandarkan kepada perbahasan yang telah dilakukan, kajian mendapati bahawa al-hajah boleh dijadikan hujah untuk mendokong dan mengharuskan kontrak pembiayaan peribadi pada hari ini. Namun, sebelum mengaplikasikan pendekatan ini perlu diperhati dan dilakukan kajian lapangan terhadap sejauh mana keperluan masyarakat terhadap pembiayaan peribadi. Dengan kajian lapangan tersebut ia dapat mendokong teori al-hajah dalam pembiayaan peribadi dalam artikel ini.

\section{Rujukan}

'Abdul Malik bin 'Abdullah (1399H). Al-Burhan fi Usul al-Fiqh. Qatar: ttp., 1399H.

'Izz al-Din ‘Abdul Salam (2000). Al-Qawa 'id al-Kubra. Damsyiq: Dar al-Qalam.

Ab. Rahim Ibrahim (2015). "Pembiayaan Peribadi Penjawat Awam di Institusi Perbankan: Kajian di Negeri Melaka." Kertas kerja dibentangkan di Persidangan Antara Bangsa Fiqh Semasa dan Perundangan Islam, Batam, Indonesia.

Amir Fazlim Yusoff \& Muhammad Shahir Ridzuan Md Radzi (2016). "Instrumen Pembiayaan Peribadi Tunai Islam di Malaysia: Satu Sorotan Literatur." Dalam Zamzuri Zakaria, Muhammad Nazir Alias, Lukman Samsudin (eds.), Prosiding Konvensyen Kebangsaan Koperasi Patuh Syariah Angkas-UKM (KONSIS 2016). Bangi: UKM. 
Muhammad Ikhlas Rosele /UMRAN - International Journal of Islamic and Civilizational Studies. Vol. 4, No. 3. (2017) 43 - 51

Al-Bahuti, Mansur bin Yunus (2000). Syarh Muntaha al-Iradat. Beirut: Mu'asasah al-Risalah.

Al-Burnu, Muhammad Sidqi bin Ahmad (2003). Mausu'ah al-Qawa'id al-Fiqhiyyah. Beirut: Mu'asasah al-Risalah.

Al-Hariri, Ibrahim Muhammad Mahmud (1998). Al-Madkhal ila al-Qawa'id al-Fiqhiyyah al-Kulliyah. 'Amman: Dar 'Ammar.

Aliftaa (t.t.). "Hukm al-Tawarruq al-Munazzam allazi Tajribah Ba'da al-Bunuk al-Islamiyyah.” aliftaa.jo http://aliftaa.jo/Decision.aspx?DecisionId=174\#.UteVLNIW0rM

Al-Jassas, Abu Bakr Ahmad al-Razi (1993). Ahkam al-Qur'an. Beirut: Dar al-Fikr.

Al-Jauziyyah, Ibn al-Qayyim (2004). I'lam al-Muwaqqi'in 'an Rabb al- 'Alamin. Kaherah: Dar al-Hadis.

Al-Jawzi, Abd Rahman bin 'Ali (1987). Zad al-Maysir fi 'Ilm al-Tafsir. ttp: al-Maktab al-Islami.

Al-Khathlan, Sa'ad bin Turki (2012). Fiqh al-Mu'amalat al-Maliyah al-Mu'asirah. Riyadh; Dar al-Sami'i.

Al-Maqdisi, Ibn Qudamah (1997). Al-Mughni. Al-Riyadh; Dar ‘Alim al-Kutub.

Al-Mumini, Ahmad Arsyid ‘Ali (2004). “Al-Hajah 'Inda al-Usuliyyin wa Atharuha fi al-Tasyri'.” Tesis PhD dalam Fiqh dan Usul, Universiti Jordan, 2004.

Al-Nawawi, Yahya bin Syaraf (2003). Rawdah al-Talibin. Al-Riyadh: Dar ‘Alim al-Kutub.

Al-Qaradawi, Yusuf (1996). Fi Fiqh al-Awlawiyat. Kaherah: Maktabah Wahbah.

Al-Suyuti, Jalal al-Din 'Abdul al-Rahman (1997). Al-Asybah wa al-Naza'ir. Riyadh: Maktabah Nizar Mustafa alBaz.

Al-Syabini, Muhammad bin al-Khatib (1997). Mughni al-Muhtaj ila Ma'rifah Ma'ani al-Faz al-Minhaj. Bayrut: Dar al-Ma'rifah.

Al-Syatibi, Ibrahim bin Musa (1997). Al-Muwafaqat. Mamlakah al-`Arabiyah al-Sa'udiyah: Dar Ibn 'Affan.

Al-Zarqa, Ahmad bin Muhammad (2001). Syarh al-Qawa'id al-Fiqhiyyah. Damsyiq: Dar al-Qalam, 2001.

Al-Zuhaili, Wahbah (2010). Usul al-Fiqh al-Islami. Damsyiq: Dar al-Fikr.

Al-Zuhayli, Wahbah (1985). Al-Fiqh al-Islami wa Adillatuh. Dimasyq: Dar al-Fikr.

Amir Shaharuddin (2013). Is Bay' al-Tawarruq A Better Alternative?. Dalam Muhammad Ridhwan Ahmad (ed.), Celebrating 30 Years of Islamic Banking And Financial Institutions In Malaysia 1983-2013, Nilai: Penerbit USIM.

Asmak Ab. Rahman, Shamsiah Mohammad \& Iman Mohd Salleh (2010). Bay' al-Tawarruq dan Aplikasinya dalam Pembiayaan Peribadi di Bank Islam Malaysia Berhad. Jurnal Syariah, 18(2): 333-360.

Azizi Abu Bakar (2009). "Pelaksanaan Bay Al-Inah dalam Pembiayaan Peribadi (Personal Loan) di Malaysia." Kertas kerja dibentangkan dalam International Conference on Corporate Law (ICCL) 2009, 1 - 3 jun 2009 , Surabaya, Indonesia..

Hussein Azeemi Abdullah Thaidi, Muhamad Firdaus Ab. Rahman \& Azman Ab. Rahman (2014). Analisa Eksistensi Gharar Terhadap Pembiayaan Peribadi Tawarruq. GJAT, 4(1): 83-95.

Ibn Nujaym (2005). Al-Asybah wa al-Nazair. Dimasyq: Dar al-Fikr.

Lajnah al-Da'imah (t.t.). "Hukm al-Tawarruq al-Masrifi al-Munazzam." alifta.net http://www.alifta.net/Fatawa/fatawaDetails.aspx?languagename=ar\&View $=$ Page $\&$ PageID $=10811 \& P a g e N o=1 \&$ BookID $=2$

Mahmud bin Muhammad ‘Ali Mahmud (2012). Ikhtilaf Ara' al-Fuqaha’ Haul al-Tatbiq Muntijat al-Tawarruq alMunazzam wa Bai’ al-`Inah wa al-Dayn fi al-Masarif al-Islamiyah. Majallah al-Islam fi Asia, 9(2). 
Muhammad Ikhlas Rosele /UMRAN - International Journal of Islamic and Civilizational Studies. Vol. 4, No. 3. (2017) 43 - 51

Mohd Daud Bakar (2011). Pembiayaan Peribadi Menurut Perspektif Syariah. Dalam Buku Program Muzakarah Penasihat Syariah Kewangan Islam. Kuala Lumpur: KLIFF.

Mohd Farhan Ahmad \& Mohd Adib Ismail (2011). Pendekatan Baru Pembiayaan Peribadi: Satu Cadangan. Dalam Prosiding PERKEM VI. Bangi: UKM.

Mohd Izuwan Mahyuddin (2015). Aplikasi Tawarruq dalam Sistem Perbankan Islam: Kajian di Bank Muamalat Malaysia Berhad. Disertasi sarjana yang tidak diterbitkan, Akademi Pengajian Islam, Universiti Malaya.

Nasrun Mohamad @ Ghazali \& Asmak Ab Rahman (2014). “Analysis of Tawaruq-Based Financing: From Shariah Risk Management Perspective". Dalam Asmak Ab Rahman, Wan Marhaini Wan Ahmad \& Shamsiah Mohamad (ed.), Islamic Economics, Banking and Finance: Concept and Critical Issues. Kuala Lumpur: Pearson Malaysia Sdn Bhd.

Nor Fadilah Bahari \& Nuzul Akhtar Baharudin (2014). "Kontrak Shariah Al-Tawarruq: Konsep Dan Aplikasinya Dalam Produk Perbankan Islam". Kertas kerja dibentangkan di Conference on Management and Muamalah (CoMM 2014), 26-27 May 2014.

Rohani Desa (2012). “Aplikasi Kaedah al-Darurah dalam Perkhidmatan Kesihatan di Malaysia.” Tesis PhD, Universiti Malaya, Kuala Lumpur, 2012.

Shamsiah Mohamad \& Ameer Azeezy Tuan Abdullah (2007). Kedudukan Mazhab Syafi'i Dalam Isu-Isu Muamalat di Malaysia. Jurnal Fiqh, 4.

Siti Aishah Kasmon \& Kamaruzaman Noordin (2014). "Analisis Pelaksanaan Tawarruq dalam Produk Pembiayaan Peribadi di Malaysia." Kertas kerja dibentangkan di International Conference on Postgraduate Research (ICPR 2014), 1-2 December 2014, Kuala Lumpur, MALAYSIA.

Walid Solah al-Din al-Zair \& Hamzah Hamzah (2010). "Dawabit al-Hajah allati Tunazzal Manzilat al-Darurah wa Tatbiqatuha 'ala al-Ijtihad al-Mu'asirah.” Majallat Jami'at Damsyiq li al- 'Ulum al-Iqtisadiyah wa al-Qanuniyah 26 , no. 2 (2010); 675-697.

Wan Jemizan W. Deraman (2010). Inah dan Tawarruq, diakses daripada http://www.utusan.com.my/utusan/info.asp? $=2010 \& \mathrm{dt}=0728 \& \mathrm{pub}=$ Utusan Malaysia\&sec=Bicara Agama\&pg $=$ ba $02 . h$ tm

Wizarah al-Awqaf wa Syu'un al-Islamiyyah (1983). Al-Mawsu'ah al-Fiqhiyyah. Kuwait: Wizarah al-Awqaf wa Syu'un al-Islamiyyah.

Zaydan, Abd al-Karim (2009). Al-Madkhal li Dirasah al-Syari'ah al-Islamiyyah. Beirut: Muasasah al-Risalah. 